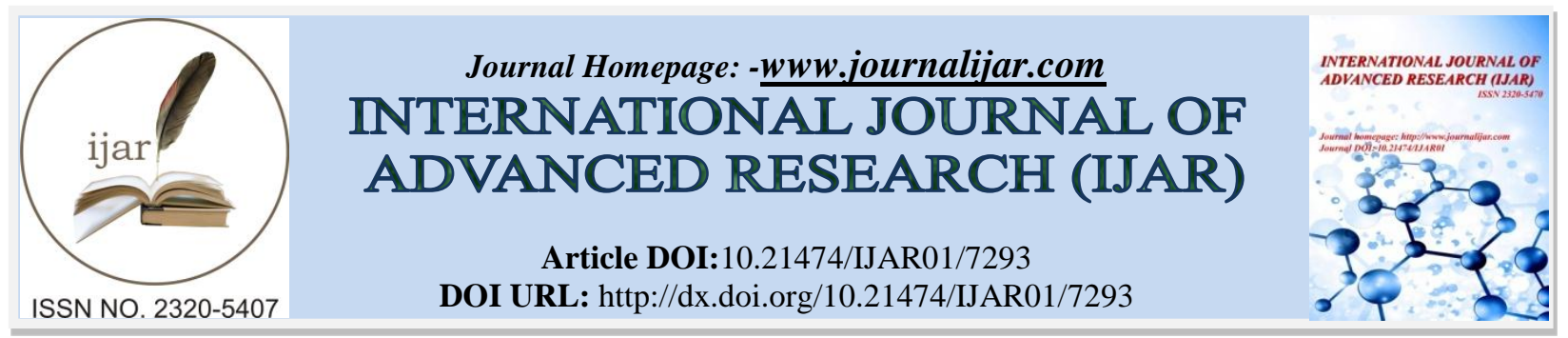

RESEARCH ARTICLE

\title{
USAGE OF EXPERT SERVICES IN THE FIELD OF LAWMAKING: FOREIGN AND NATIONAL EXPERIENCE.
}

\begin{abstract}
Khayitov Khushvakt Saparbayevich.
Ph.D., a doctoral candidate (DSc) at the Academy of Public Administration under the President of the Republic of Uzbekistan.
\end{abstract}

\section{Manuscript Info}

Manuscript History

Received: 15 April 2018

Final Accepted: 17 May 2018

Published: June 2018

\section{Keywords:-}

expertise, expert, lawmaking, draft laws, legislative techniques, legal expertise, mechanism of carrying out expertise.

\begin{abstract}
The countries differ from each other based on the culture, nation, geographic location, customs and histories. Based on these various aspects of countries, the countries conduct their own way of governance and process of making law. Therefore, the article focuses on explore law making process in different countries. The main point of the article explores the importance theoretical and legal issues of scientific expertise of draft laws in national and foreign countries. At the same time, the peculiarities of such examinations, their types, as well as proposals for improving the organizational and legal mechanisms for the implementation of expertise have been developed.
\end{abstract}

Copy Right, IJAR, 2018,. All rights reserved.

\section{Introduction:-}

In many countries, legislative activity is recognized as the most important state's functions, therefore the rules of lawmaking, expertise of draft laws that largely ensure the quality of the adopted laws are contained in the basic laws of states - in constitutions, constitutional or organic laws. In more detail, the ordinary law or the parliament's regulation, which is often adopted in the form of a law, can regulate the legislative process.

At the same time, one of the urgent tasks is the implementation of new tasks based on a deep analysis of the reform of the path taken by each country and the elimination of existing problems. In this direction, the identification and eradication of factors that adversely affect development in various sectors of the economy is an urgent importance. Ensuring fulfillment of this task requires a special approach in lawmaking process. In our opinion, improving the expert support of lawmaking activity is manifested as an effective way to solve the problems of legislation. Since, examination of regulatory legal acts is one of the forms of assessing the quality of a normative legal act.

It should be noted that there is a great interest in exporting lawmaking activities in foreign countries. For example, Tatishvili (2015) quoted that "The world community has long established for itself the importance of conducting expert analysis of draft laws, which was fixed in the legislation of different countries in their legal norms" ${ }^{1}$.

\footnotetext{
${ }^{1}$ Tatishvili T.M. International experience of expert support of lawmaking. Bulletin of the Moscow University of the Ministry of Internal Affairs of Russia. - M.: 2015, № 1. - C. 58.
} 
As a whole, subjects engaged in expert activity in the field of lawmaking are created by the parliament, the president, the government, in some cases, by the ministries. In accordance with this, expert entities involved in the legislative activities of foreign countries can be conditionally divided into three groups.

The first group, which includes the examination of the parliament and its structural units. As an example of such a structure, it indicates parliamentary committees and commissions, research centers (services) with the parliament, institutes, bureaus, libraries, supplying it with information and analysis materials ${ }^{2}$.

The second group, the subjects of lawmaking, the examination of other central government bodies, as well as various institutions. As an example of such a structure, it can be specified the president, the government and other central government bodies. In all countries, in the provision of public policy in the field of lawmaking, examination of draft laws, an important role is played by ministries of justice.

The third group is non-state actors cooperating with state bodies in the field of lawmaking.

In lawmaking, the main and final expert assessment is carried out by the parliament, meanwhile, an the main role belongs to the government in the preparation and improvement of draft laws. Since, "Along with the implementation of regulatory authority, the government has power that have a serious, sometimes decisive influence on the legislative process. In world practice, almost all countries (except the United States of America) the legislative initiative belongs to the government. As evidenced by the statistics of the parliaments of Western European countries, most of the projects approved in parliament and gaining legal force are represented by the government. In general, the government makes extremely effective use of the rights to legislative initiative, which is part of its mandate." ${ }^{3}$ In this regard, the most important and numerous checks in lawmaking are conducted on the initiative of the government. Especially, the Ministry of Justice, which is part of the government, has a direct responsibility for the quality and thorough development of draft laws.

In the United States in the preparation of bills are actively involved in numerous organizations engaged in scientific and research activities. Using the country's theoretical and practical experience, summarizing it, they develop recommendations for state legislatures on the unification of legislation. This experience makes an important contribution to the development of US law. As a striking example of such an organization, it points to an organization called the National Conference of Comissioners on Uniform State Laws. Thanks to the merits of this organization, the country's Single Trade Code was adopted in the same form in all states (only Louisiana joined some parts) ${ }^{4}$.

At the same time, such research institutes as the Institute of Legal Studies, the American Society of Comparative Law, The Institute of Law and Behavioral Studies, American Institute of Law are involved in the improvement of lawmaking.

It should be noted that the US Parliament has developed expertise in providing expert support. The Congressional Research Service, which contributes to the implementation of legislative, monitoring and representation functions of the US Congress, plays an important role in the substantiation of bills. This structure, in accordance with the Law on the Transformation of the Legislature, was created in the form of the Legislative Information Service and it was renamed as the Congressional Research Service in 1970. Since then, expertise is recognized as an integral part of the adoption of important decisions taken in the activities of the Congress.

The Congressional Research Service provides objective, analytical, and research information to all members and committees of the Congress. Currently, the Congressional Research Service is the central part of a large-scale information and analytical assistance system, which includes the General Accounting Office and the Budget Office of the Congress.

\footnotetext{
${ }^{2}$ Papazoski Z. Development of Parliamentary Research Services in Central Europe and the Western Balkans. Bratislava, National Democratic Institute for International Affairs. 2013. - P. 65-66.

${ }^{3}$ Khashimkhanov A.M. Law-making activity of Cabinet of Ministers of the Republic of Uzbekistan: theory and practice issues. PhD dissertation. - Tashkent: 2008, - P. 44.

${ }^{4}$ Ramon L. Great legal systems of the present: legal approach. - M., Volter Kruver, 2010. - P. 145.
} 
The main thing is that experts of this institution can not be members of the same party, they must conduct an independent, objective research, through which to provide expert services 5 .

In the Lower Chamber of the Parliament, an important role belongs to the specialized committees and subcommittees in carrying out various examinations and appointing additional examinations. The Responsible Committee ensures that all agencies, committees and departments involved in the legal proceedings are involved in the discussion of projects. In necessary cases, in order to carry out public expertise, draft laws may be sent to public entities ${ }^{6}$.

In Germany, draft laws are first sent to the Federal Ministry of Justice to obtain the consent of the federal government concerned, to identify compliance with current legislation and regulations of legislative technique. The Federal Ministry of Justice conducts an expert expertise on the language of law and legal technique. The Federal Ministry of Justice has the right to verify the compliance of the law with the current legislation and in terms of its language ${ }^{7}$.

The bill is submitted to the Bundestag in order to put on the agenda of the factions and relevant committees. If the bill relates to other spheres, other parties may be involved in the process, depending on their prudence. Examination of the draft laws considered in the Bundestag is carried out by the Research Departments established by the eleven directions of the Research Service (created proportionally to the social and legal sectors) ${ }^{8}$.

In the statement on "Compliance of laws and resolutions with the law in force and their Identity", announced on July 10, 1991, recommendations were developed for the provision of legal guidance in a single form.

Papazosky noted that 31 out of 37 states located on the European continent are established special studies and provision of analytical services. In the remaining six states, this task is entrusted to other structures within the parliament. For example, Austria, Denmark and Croatia, this function is entrusted to the parliamentary library ${ }^{9}$.

When studying the activities of the Parliament of Denmark - Folketing, then the provision of analytical data is carried out by the library with the Secretariat of Parliament or parliamentary committees. If necessary, they can involve scientists and specialists of this field ${ }^{10}$.

Now in parliaments of CIS and Baltic countries various information and analytical services as at the level of managements (Information management of the Office of the Verkhovna Rada of Ukraine, Information management of the Office of National Assembly of the Republic of Armenia). Moreover, at the level of departments are created (Department of analytical operation of the Office of the House of Representatives of National Assembly of Republic of Belarus, the Information and analytical sector of the Center for parliamentary researches and public relations of Parliament of the Republic of Moldova, Department of information support of the Device of Millie of Majlis of the Azerbaijan Republic, Department of information and analytical operation of the Office of Mazhilis of the Republic of Kazakhstan, Department of economic and social information of Office of the Riigikogu of the Republic Estonia, information and analytical departments of offices of Diets of the republics Lithuania and Latvia, etc.). In the experience of some countries, there are norms concerning the conduct of scientific expertises. In particular, the Law of the Republic of Kazakhstan "On normative legal acts" provides that draft legislative acts and other regulatory documents that may pose a threat to the environment, including in the areas of radiation, safety and environmental protection, must undergo mandatory scientific and ecological expertise ${ }^{11}$.

\footnotetext{
${ }^{5}$ Annual report Congressional Research Service Fiscal Year 2016. - Washington: Library of Congress. 2017. - P.1. // www.loc.gov

${ }^{6}$ How a bill becomes a law / V.Consideration by committee // http://www.opencongress.org

${ }^{7}$ Handbook of standard-setting technology / Handbuch der Rechtsformlichkeit. - M., Бек, 2002. - P. 296

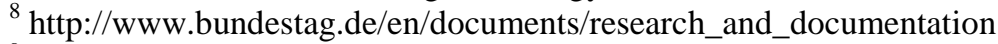

${ }^{9}$ Papazoski Z. Development of Parliamentary Research Services in Central Europe and the Western Balkans. Bratislava, National Democratic Institute for International Affairs. 2013. - P. 63.

${ }^{10} \mathrm{http}: / / \mathrm{www}$. thedanishparliament.dk

${ }^{11}$ The Law of the Republic of Kazakhstan "On normative legal acts" № 480-V 3РК, 6 April 2016 // www.zakon.kz
} 
If we address experience of the Verkhovna Rada of Ukraine, then we will see that the norm on obligation of conducting scientific examination of the bills prepared for the first reading according to the agenda is provided ${ }^{12}$.

In addition, the Government of Kazakhstan approved the Rules for the scientific expertise of draft normative and legal acts, and the procedure for conducting this examination is determined. In accordance with this, scientific expertise of normative legal acts is carried out for the following purposes:

1. Assessment of the quality, validity, timeliness and legality of the project, ensuring human rights and the rights of citizens, enshrined in the Constitution of the Republic of Kazakhstan;

2. Determination of the possible effectiveness of the normative legal act;

3. Identification of negative consequences resulting from the adoption of the project as a normative legal act ${ }^{13}$.

In Ukraine, the examination of draft laws is carried out by following procedure: after the bill is submitted by the subject of the legislative initiative to the Verkhovna Rada of Ukraine, the draft is sent to the main committee of the Verkhovna Rada Apparatus and the scientific-expert board. The Scientific-expert Board, conducts expertise on its relevance, compliance with legislation, language and analysis of social, economic and other consequences of its adoption before consideration of the bill in the first reading. The conclusion of the Scientific-expert board for adoption of the draft law in the first reading is submitted to the deputies without fail. After the adoption of the bill in the first reading, it passes mandatory legal expertise in the legal department of the Verkhovna Rada. In the process of expertise, the bills are found to comply with the existing legal system, as well as compliance with its preparation of the rules of legislative technology

Therefore, the legislative process of Ukraine specifies achievement the goals and subjects of scientific and legal expertise. At the first stage, the expertise is carried out by the Scientific-expert board of Apparatus of the Verkhovna Rada, at the next stages, that is, after the adoption of the bill in the first reading, - the legal department of Apparatus of the Verkhovna Rada ${ }^{14}$.

In the legislative activity of the Republic of Belarus has been formed positive experience in the use of information technologies. According to legislative activity, the computer program "Automated system for the development of draft normative and legal acts of the Republic of Belarus" is widely used in state bodies engaged in norm-setting activities. This program was created in order to further improve the technology of preparation of regulatory and legal acts, on the basis of generalization of practice on the development of norms of state bodies of the Republic of Belarus $^{15}$.

With the help of the program in an automated mode, the selection of draft normative legal acts and their creation. The program consists of folders that are stored more than 100 variants of templates. At the same time, with the help of the program, it is possible to consider the rules of legislative technology in the constituent parts of draft normative legal acts. Thereby "Legislative information systems are computer tools that help, streamline, and manage the activities of legislative offices, mostly the back-office activities of a national parliament or of any assembly entrusted with legislative power. Although the largest part of these tools are not in direct contact with the general population, they have an indirect, yet very important effect on it, and their systematic and correct use can concretely improve the efficiency and transparency of the democratic processes they support" ${ }^{\prime 16}$.

Thus, as follows from the lawmaking practice of many foreign countries, special attention is paid to the expert analysis of draft laws when drafting laws. At the same time, there are special institutions for the examination and evaluation of bills in terms of their language. These institutions make a great contribution to the improvement of the language of laws. The implementation of such positive experience in the Republic of Uzbekistan will also lead to

12 Law of Ukraine "On the Regulations of the Verkhovna Rada of Ukraine" on February 10, 2010 // www.iportal.rada.gov.ua

${ }^{13}$ Rules for the scientific review of draft normative legal acts. 31 августа 2016 года // www.zakon.kz

${ }^{14}$ Xodjayev M. (2005) The conclusion of the draft law is an important prerequisite for the preparation of quality laws. / Problems of expertise of legislative acts. Materials of scientific-practical seminar. - Tashkent, 2005. - P. 70 71.

${ }^{15} \mathrm{http}: / /$ center.gov.by/normotvorcheskaya-deyatel-nost

${ }^{16}$ Palmirani M, Vitali F. Legislative Drafting Systems. Usability in Government Systems: User experience design for citizens and public servants. 2012,- P. 133. // www.sciencedirect.com 
positive results. In particular, the responsibly bodies will establish an important role in lawmaking process, it is necessary to establish the activities of special structures dealing with language issues.

It should be noted that the primarily priorities of the Strategy of Actions for the five sphere of development directions of the Republic of Uzbekistan in 2017-2021. It is planned to radically improve the quality of lawmaking activity with increasing impact of the adopted laws on the socio-political, socioeconomic and judicial-legal reforms being implemented, the implementation of which is scheduled for the next five years.

One of the important steps in the implementation of the tasks, the envisaged in the Strategy of Actions was establishment of the Institute for Problems of Legislation and Parliamentary Studies on the basis of the joint decision of the Legislative Chamber of the Oliy Majlis and the Kengash Senate of the Oliy Majlis of the Republic of Uzbekistan as of 29 December $2017^{17}$.

\section{Conclusion:-}

Summing up the result of the aforesaid, we consider expedient promotion of the following offers promoting further improvement of quality of laws and strengthening of "viability" of acts:

1. Firstly, the adoption of the law "On expertise of draft normative legal acts" which provides for a comprehensive regulation of relations relating to expert provision of lawmaking and rulemaking;

2. Secondly, at all stages of lawmaking activities, the expansion of the conduct of qualified expertise in various areas. Develop provisions and procedures for individual types of expertise (scientific, economic, public, etc.);

3. Thirdly, the expansion of the practice of independent public expertise in drafting regulatory and legal acts. Stimulating creative initiatives in this direction.

\section{Reference:-}

1. Tatishvili T.M. (2015), International experience of expert support of lawmaking. Bulletin of the Moscow University of the Ministry of Internal Affairs of Russia. - № 1. - C. 58.

2. Papazoski Z. (2013), Development of Parliamentary Research Services in Central Europe and the Western Balkans. - Bratislava, National Democratic Institute for International Affairs. - P. 65-66.

3. Khashimkhanov A.M. (2008), Law-making activity of Cabinet of Ministers of the Republic of Uzbekistan: theory and practice issues. PhD dissertation. - Tashkent: - P. 44.

4. Ramon L. (2010), Great legal systems of the present: legal approach. - M., Volter Kruver, - P. 145.

5. Annual report (2017) Congressional Research Service Fiscal Year 2016. - Washington: Library of Congress. P.1. // www.loc.gov

6. How a bill becomes a law /V.Consideration by committee // http://www.opencongress.org

7. Handbook of standard-setting technology (2002) / Handbuch der Rechtsformlichkeit. - М., Бек,- P. 296

8. Papazoski Z. (2013) Development of Parliamentary Research Services in Central Europe and the Western Balkans. - Bratislava, National Democratic Institute for International Affairs. 2013. - P. 63

9. The Law of the Republic of Kazakhstan "On normative legal acts" № 480-V ЗРК, 6 April 2016 // www.zakon.kz

10. Law of Ukraine (2010) "On the Regulations of the Verkhovna Rada of Ukraine" on February 10, // www.iportal.rada.gov.ua

11. Rules for the scientific review of draft normative legal acts. 31 августа 2016 года // www.zakon.kz

12. Xodjayev M. (2005) The conclusion of the draft law is an important prerequisite for the preparation of quality laws. / Problems of expertise of legislative acts. Materials of scientific-practical seminar. - Tashkent, 2005. - P. $70-71$

13. Palmirani M, Vitali F. (2012) Legislative Drafting Systems. Usability in Government Systems: User experience design for citizens and public servants. 2012, - P. 133. // www.sciencedirect.com.

\footnotetext{
${ }^{17}$ www.parliament.gov.uz
} 